Виг. 1, 2019

УДК 62-83-52:621.313.3

I. 3. Щур

Національний університет “Львівська політехніка”, кафедра електромехатроніки і комп’ютеризованих електромеханічних систем, i_shchur@meta.ua

Т. Я. Дзьоба

Національний університет "Львівська політехніка", кафедра електромехатроніки і комп'ютеризованих електромеханічних систем, tdzoba@gmail.com,

П. Й. Голубовський Національний університет “Львівська політехніка", кафедра електромехатроніки і комп’ютеризованих електромеханічних систем, sumixlviv@ukr.net

\title{
ЛЮДИНО-МАШИННЕ КЕРУВАННЯ ОДНОВІСНИМ ДВОКОЛІСНИМ ПЕРСОНАЛЬНИМ ЕЛЕКТРИЧНИМ ТРАНСПОРТНИМ ЗАСОБОМ ЗА УМОВИ ЛІНІЙНОГО РУХУ
}

https://doi.org/10.23939/sepes2019.01.074

() Щур І. З., Дзьоба Т. Я., Голубовський П. Й., 2019

Розглянуто новий вид персонального електричного транспортного засобу (ЕТ3) сегвей, чи гіроборд, у якому користувач під час керування рухом бере безпосередню участь у балансуванні свого положення відносно осі, що з'єднус два колеса 3 індивідуальними електроприводами. Такий ЕТЗ - складна людино-машинна система, робота якої залежить від команд людини та відповідної реакції системи автоматичного керування (САК) рухом. Тому для розроблення останньої необхідно знати як закономірності роботи електромеханічної системи цього ЕТ3, так і навички керування, які набув користувач. На основі рівняння Лагранжа II роду розроблено математичну модель кінематики руху такого ЕТЗ у вигляді нелінійної системи взаємозв'язаних диференціальних рівнянь другого порядку. Як системи електроприводів коліс застосовано замкнені за струмами якоря синхронні машини із постійними магнітами, які керуються транзисторними інверторами напруги за положенням їх роторів відповідно до сигналів, отриманих від встановлених на колесах енкодерів. Завдання на електромагнітні моменти приводів коліс формують ПД-регулятори за сигналами від системи давачів твердотільних гіроскопа та акселерометра, які дають змогу визначити кут нахилу тіла користувача. За розробленою функціональною схемою системи "користувач - гіроборд" у середовищі Matlab/Simulink створено імітаційну комп'ютерну модель, в яку входить розроблена математична модель кінематики руху гіроборда із користувачем. Ця модель імітус поведінку користувача, а також роботу САК електроприводами коліс. Визначено раціональні налаштування регуляторів моделі. У результаті проведеного комп'ютерного симулювання циклу руху гіроборда отримано низку осцилограм основних координат, 
Людино-машинне керування одновісним двоколісним персональним електричним транспортним засобом ...

що описують динаміку системи. Вони дали змогу зрозуміти закономірності взаємодії людини і машини та показали працездатність розроблених підходів до побудови системи керування гіробордом.

Ключові слова: персональний електричний транспортний засіб; сегвей; гіроборд; самобалансування; людино-машинна система.

\section{Постановка задачі}

Мобільний персональний електротранспорт завойовує все більше прихильників і масову популярність у всьому світі [1]. Крім електровелосипедів та інших електробіциклів, які належать до класу двоколісних двоосьових персональних електричних транспортних засобів (ЕТЗ), останнім часом набув поширення клас двоколісних одновісних ET3 у вигляді сегвея (Segway) та гіроборда (гіроскутера) [2-4]. Це персональний ЕТЗ у вигляді платформи для ніг, двох коліс із привідними електродвигунами, що встановлені на одній осі, перпендикулярній до напрямку руху, акумуляторної батареї для живлення електроприводу, а також вбудованої силової та мікроелектроніки для керування рухом. Відмінність між сегвеєм та гіробордом полягає у пристроях для виконання поворотів: у сегвея це встановлений на платформі джойстик, яким керують за допомогою колін, а в гіроборда - розділена навпіл платформа, що дає змогу задавати кут повороту за допомогою різниці в кутах нахилу півплатформ (рис. 1). Кожна із моделей має певні переваги і недоліки, а також технічні характеристики щодо маси пасажира, діаметра коліс, потужності приводів, ємності акумуляторної батареї та відповідно дальності ходу і використаних матеріалів. Однак щодо керування ці персональні ЕКЗ принципово не відрізняються. Тому в подальшому описі послуговуватимемося назвою “гіроборд”.

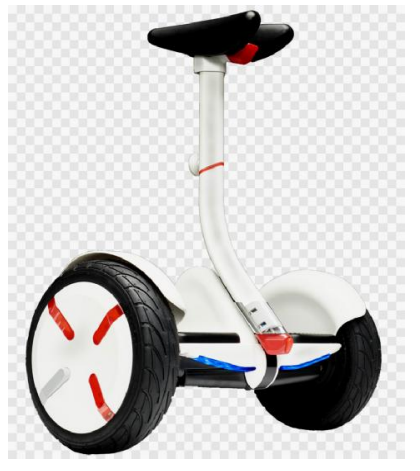

$a$

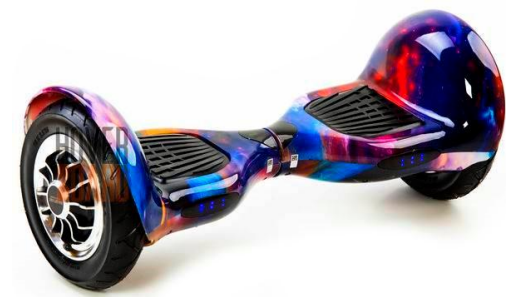

б

Рис. 1. Зовнішній вигляд: $a-$ сегвей; б-гіроборд

Гіроборд - складний людино-машинний комплекс, робота якого залежить від команд людини та відповідної реакції системи автоматичного керування (САК). Тому для розроблення останньої необхідно знати як закономірності роботи електромеханічної системи цього ЕТЗ, так і можливості користувача щодо керування.

\section{Аналіз останніх досліджень і публікацій}

Гіроборд із користувачем як об’єкт керування є доволі складною нелінійною та нестабільною системою [2]. У разі відсутності користувача на ЕТЗ центр ваги платформи гіроборда буде нижче від осі коліс. Тоді система поводитиметься як простий маятник, і це робить її стійкою. Наявність користувача зумовлює переміщення центра мас значно вище від осі коліс, що перетворює звичайний маятник на перевернутий, тобто нестійкий [5]. Для його стабілізації під час руху гіроборда необхідно поєднати роботу користувача із функціонуванням САК рухом. В основу цього поєднання покладено технологію динамічної стабілізації - 
один із найголовніших принципів теорії та практики сучасного автоматичного керування динамікою інверсного маятникового важеля [6].

У багатьох наукових публікаціях на тему персональних ЕТ3 розглядають переважно питання механічного проєктування та електромеханічного конструювання $[7,8]$. Проте низка робіт стосується автоматичного керування [9-15]. Найпоширенішим способом автоматичної стабілізації інверсного маятника є застосування ПІД-регуляторів. Крім класичного ПІД-регулятора [9], для забезпечення якості керування додатково застосовують функції самоналаштування [10], а також фільтрування шумів із давачів (акселерометр, гіроскоп, кутомір) за допомогою фільтра Калмана $[11,12]$. Проте у вказаних роботах для синтезу систем керування складну нелінійну модель об'єкта, як правило, спрощували за допомогою лінеаризації. У роботах $[13,14]$ для подолання вказаного недоліку застосовано нечітке керування, що дало задовільний результат, проте налаштування нечіткої САК суб'єктивне. Ще складнішу реалізацію у вигляді дискретного контролера 12-го порядку розроблено із використанням методик $\mu$-синтезу [15].

Аналіз стану проблеми керування гіробордом свідчить про актуальність досліджень, спрямованих на створення САК, яка враховує нелінійність та нестабільність об'єкта керування та участь людини у процесі стабілізації цього ЕТЗ.

\section{Мета статті}

Метою роботи є створення на основі методів аналітичної механіки математичної моделі гіроборда, розроблення системи керування самобалансуванням із розподілом функцій між користувачем і САК рухом та проведення симуляційних досліджень на створеній комп’ютерній моделі системи.

\section{Математичне моделювання об'єкта керування}

\section{Виклад основного матеріалу}

Математичну модель руху будь-якої механічної системи можна визначити із рівнянь Лагранжа другого роду, які подаються залежністю загального вигляду [16]:

$$
\frac{\mathrm{d}}{\mathrm{d} t}\left(\frac{\partial}{\partial \dot{q}_{k}} L\right)-\frac{\partial}{\partial q_{k}} L+\frac{\partial}{\partial \dot{q}_{k}} \Phi=Q_{k}, \quad k=1, \ldots, n,
$$

де $L=T-V$ - лагранжіан; $T$ - сумарна кінетична енергія системи; $V$ - сумарна потенціальна енергія системи; $\Phi$ - сумарна потужність розсіяння енергії в системі (функція дисипації Релея); $q_{\mathrm{k}}-k$-та із незалежних узагальнених координат; $Q_{\mathrm{k}}$ - узагальнена непотенціальна сила, що діє на частину системи із $k$-ю координатою; $n$ - кількість незалежних узагальнених координат.

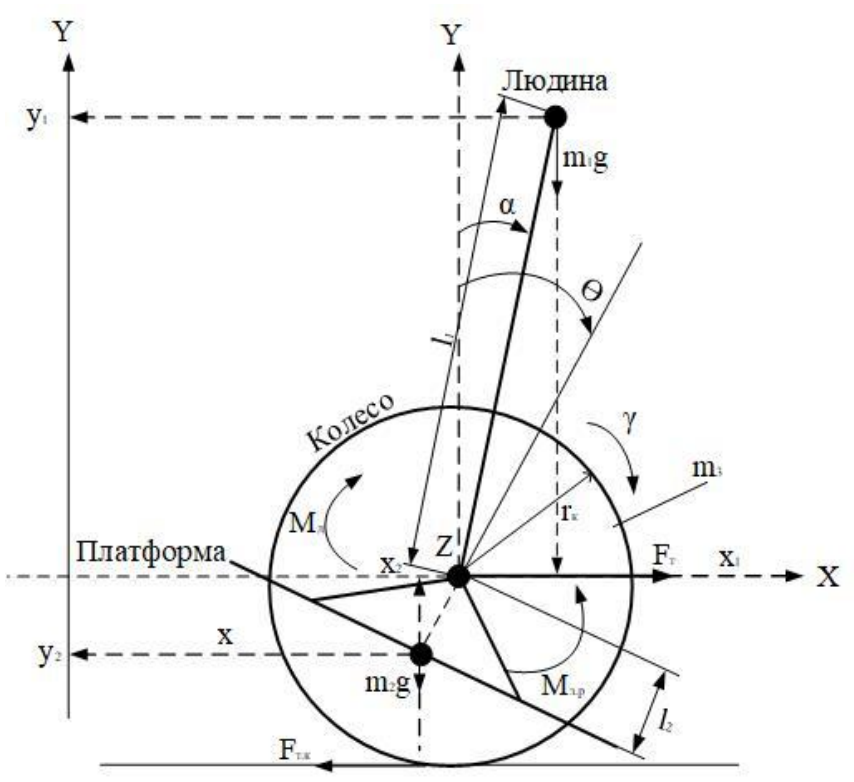

Рис. 2. Геометрична модель гіроборда

У досліджуваному об'єкті можна виділити три зосереджені маси, які рухаються у своїх системах координат та взаємодіють між собою (рис. 2):

1) людина (пасажир та водій в одній особі) 3 центром мас у точці 1; ця маса здійснює обертовий рух відносно початку координат 0 та поступальний рух разом із візком у напрямку $x$;

2) платформа візка (разом із двигунами, акумуляторами та ступнями людини, які вважатимемо встановленими на платформі без ковзання); ця маса теж здійснює обертовий рух відносно початку координат 0 та поступальний рух разом із візком у напрямку $x$;

3) колеса візка, які теж здійснюють обертовий рух відносно початку координат 0 та поступальний рух разом із візком у напрямку $x$. 
Людино-машинне керування одновісним двоколісним персональним електричним транспортним засобом ...

Узагальнені координати для цих зосереджених мас виберемо такими:

перша маса (обертовий рух) - кут нахилу $\alpha$ людини відносно вертикальної осі $y$;

друга маса (обертовий рух) - кут відхилення $\theta$ платформи від статичного положення щодо вертикальної осі $y$;

третя маса (обертовий рух) - кут повороту $\gamma$ коліс відносно початкового положення (oci y);

усі три маси (поступальний рух) - положення на осі $x$.

Конструкція механічної частини гіроборда передбачає, що гомілковостопні суглоби користувача і вісь коліс будуть на тій самій осі. Така конструкція підвищує комфорт користувача i стабільність системи. Тому перша і друга маси зв'язані між собою шарнірно гомілковостопними суглобами людини, які характеризуються коефіцієнтом жорсткості на згин $c_{1-2}$ та коефіцієнтом внутрішнього в'язкого тертя $b_{1-2}$. Друга і третя маси сполучені лише силовим способом - за допомогою обертових моментів. Отже, у досліджуваній системі з трьома узагальненими масами та чотирма незалежними рухами $n=3$.

Відповідно до системи координат $x-y$, показаної на рис. 2, координати центрів мас трьох вказаних узагальнених мас є такими:

перша маса

$$
x_{1}=x+l_{1} \sin \alpha ; \quad y_{1}=l_{1} \cos \alpha ;
$$

друга маса

$$
x_{2}=x-l_{2} \sin \theta ; \quad y_{1}=-l_{2} \cos \theta ;
$$

третя маса

$$
\dot{x}_{3}=\dot{x} ; \quad \dot{y}_{3}=0 .
$$

У центрах мас із координатами (2)-(4) відповідно розміщені маси: $m_{1}$ - людини, $m_{2}-$ платформи візка, $m_{3}$ - одного колеса візка. 3 метою спрощення доцільно обертовий рух коліс привести до їх поступального руху. Тоді третя еквівалентна приведена до поступального руху гіроборда маса коліс дорівнюватиме

$$
m_{3}^{\prime}=2\left(m_{3}+\frac{J_{\mathrm{\kappa}}}{r_{\mathrm{\kappa}}^{2}}\right),
$$

де $J_{\mathrm{K}}$ - момент інерції одного колеса гіроборда; $r_{\mathrm{\kappa}}$ - радіус колеса гіроборда.

Проєкції швидкостей трьох мас на осі системи координат $x-y \in$ такими:

$$
\begin{gathered}
\dot{x}_{1}=\dot{x}+l_{1} \dot{\alpha} \cos \alpha ; \quad \dot{y}_{1}=-l_{1} \dot{\alpha} \sin \alpha ; \\
\dot{x}_{2}=\dot{x}-l_{2} \dot{\theta} \cos \theta ; \quad y_{1}=l_{2} \dot{\theta} \sin \theta ; \\
\dot{x}_{3}=\dot{x} ; \quad \dot{y}_{3}=0 .
\end{gathered}
$$

Сумарна кінетична енергія системи, яка характеризує усі чотири рухи, описується таким виразом:

$$
T=\frac{1}{2} \sum_{i=1}^{3} m_{i}\left(\dot{x}_{i}^{2}+\dot{y}_{i}^{2}\right) \text {. }
$$

Підставляючи в рівняння (9) вирази (5)-(8), після перетворень отримуємо

$$
T=\frac{1}{2}\left[m_{1} l_{1}^{2} \dot{\alpha}^{2}+m_{2} l_{2}^{2} \dot{\theta}^{2}+2 m_{1} l_{1} \dot{x} \dot{\alpha} \cos \alpha-2 m_{2} l_{2} \dot{x} \dot{\theta} \cos \theta+\left(m_{1}+m_{2}+m_{3}^{\prime}\right) \dot{x}^{2}\right] \text {. }
$$

Сумарна потенціальна енергія системи складається із потенціальної енергії, що нагромаджується у пружному зв'язку між першою та другою зосередженими масами, та потенціальної енергії цих мас із урахуванням їх відхилення від стану рівноваги. Відповідно до рис. 2 можна записати

$$
V=\frac{1}{2} c_{1-2}(\alpha-\theta)^{2}+m_{1} g l_{1} \cos \alpha+m_{2} g l_{2}(1-\cos \theta) .
$$

Сумарна потужність розсіяння енергії в системі складається із потужностей, що розсіюються через внутрішне в'язке тертя під час коливань пружного зв'язку між першою та другою 


\section{3. Щур, Т. Я. Дзьоба, П. Й. Голубовський}

зосередженими масами, та потужностей зовнішнього в'язкого тертя в опорах обертання другої та третьої зосереджених мас:

$$
\Phi=\frac{1}{2} b_{1-2}(\dot{\alpha}-\dot{\theta})^{2}+b_{2} \dot{\theta}^{2}+b_{3}\left(\frac{\dot{x}}{r_{\mathrm{K}}}\right)^{2},
$$

де $b_{i}$ - коефіцієнт зовнішнього в'язкого тертя в опорах обертання $i$-ї зосередженої маси.

Зовнішні сили непотенціального характеру, що діють в напрямку кожної із координат руху, $\epsilon$ такими:

$$
\begin{gathered}
Q_{1}=-M_{\text {з.p }} ; \\
Q_{2}=M_{\text {з.p }}-M_{\text {д }}-M_{\mathrm{c} .2} ; \\
F_{3}=\frac{M_{\text {д }}-M_{\mathrm{c} .3}}{r_{\mathrm{K}}}-F_{\mathrm{T} . \mathrm{K}},
\end{gathered}
$$

де $M_{3 . p}$ - момент для задання руху, який створює людина, нахиляючись; $M_{\partial}-$ момент, що створюють електродвигун; $M_{c . i}-$ момент сухого тертя в опорах $i$-ї зосередженої обертової маси; $F_{m . \kappa}$ - сила опору тертя кочення гіроборда.

Лагранжіан системи з урахуванням (10) та (11) матиме такий вигляд:

$$
\begin{gathered}
L=\frac{1}{2}\left[m_{1} l_{1}^{2} \dot{\alpha}^{2}+m_{2} l_{2}^{2} \dot{\theta}^{2}+2 m_{1} l_{1} \dot{x} \dot{\alpha} \cos \alpha-2 m_{2} l_{2} \dot{x} \dot{\theta} \cos \theta+\left(m_{1}+m_{2}+m_{3}^{\prime}\right) \dot{x}^{2}-\right. \\
\left.-c_{1-2}(\alpha-\theta)^{2}\right]-m_{1} g l_{1} \cos \alpha-m_{2} g l_{2}(1-\cos \theta)
\end{gathered}
$$

Щоб отримати математичну модель руху системи гіроборда, необхідно підставити одержані вирази (12)-(16) в рівняння (1) та здійснити почергово диференціювання для кожної із трьох узагальнених координат руху.

Візьмемо спочатку часткові похідні лагранжіана (16) за швидкостями руху $\dot{\alpha}, \dot{\theta}, \dot{x}$ (часткові похідні в дужках у виразі (1)). Відповідно отримуємо такі результати:

$$
\begin{gathered}
\frac{\partial}{\partial \dot{\alpha}} L=m_{1} l_{1}\left(l_{1} \dot{\alpha}+\dot{x} \cos \alpha\right) \\
\frac{\partial}{\partial \dot{\theta}} L=m_{2} l_{2}\left(l_{2} \dot{\theta}-\dot{x} \cos \theta\right) \\
\frac{\partial}{\partial \dot{x}} L=m_{\Sigma} \dot{x}+m_{1} l_{1} \dot{\alpha} \cos \alpha-m_{2} l_{2} \dot{\theta} \cos \theta
\end{gathered}
$$

де $m_{\Sigma}=m_{1}+m_{2}+m_{3}^{\prime}$ - узагальнена маса поступального руху гіроборда.

Часові похідні виразів (17)-(19) відповідно дорівнюють

$$
\begin{gathered}
\frac{\mathrm{d}}{\mathrm{d} t}\left(\frac{\partial}{\partial \dot{\alpha}} L\right)=m_{1} l_{1}\left(l_{1} \ddot{\alpha}+\ddot{x} \cos \alpha-\dot{\alpha} \dot{x} \sin \alpha\right) ; \\
\frac{\mathrm{d}}{\mathrm{d} t}\left(\frac{\partial}{\partial \dot{\theta}} T\right)=m_{2} l_{2}\left(l_{2} \ddot{\theta}-\ddot{x} \cos \theta+\dot{\theta} \dot{x} \sin \theta\right) . \\
\frac{\mathrm{d}}{\mathrm{d} t}\left(\frac{\partial}{\partial \dot{x}} L\right)=m_{\Sigma} \ddot{x}+m_{1} l_{1} \ddot{\alpha} \cos \alpha-m_{2} l_{2} \ddot{\theta} \cos \theta-m_{1} l_{1} \dot{\alpha}^{2} \sin \alpha+m_{2} l_{2} \dot{\theta}^{2} \sin \theta .
\end{gathered}
$$

Часткові похідні лагранжіана (16) за координатами руху отримано у вигляді

$$
\begin{gathered}
\frac{\partial}{\partial \alpha} L=-m_{1} l_{1} \dot{x} \dot{\alpha} \sin \alpha-c_{1-2}(\alpha-\theta)+m_{1} g l_{1} \sin \alpha ; \\
\frac{\partial}{\partial \theta} L=m_{2} l_{2} \dot{x} \dot{\theta} \sin \theta+c_{1-2}(\alpha-\theta)-m_{2} g l_{2} \sin \theta ; \\
\frac{\partial}{\partial x} L=0 .
\end{gathered}
$$


Людино-машинне керування одновісним двоколісним персональним електричним транспортним засобом ...

Часткові похідні потужності розсіяння (12) за швидкостями руху відповідно дорівнюють

$$
\begin{gathered}
\frac{\partial}{\partial \dot{\alpha}} \Phi=b_{1-2}(\dot{\alpha}-\dot{\theta}) ; \\
\frac{\partial}{\partial \dot{\theta}} \Phi=-b_{1-2}(\dot{\alpha}-\dot{\theta})+2 b_{2} \dot{\theta} ; \\
\frac{\partial}{\partial \dot{x}} \Phi=\frac{2 b_{3}}{r_{\mathrm{k}}^{2}} \dot{x} .
\end{gathered}
$$

Щоб сформувати кінцеву математичну модель руху гіроборда 3 користувачем, необхідно підставляти почергово в (1) такі отримані вирази: (20), (23), (26) і (13); (21), (24), (27) і (14); (22), (25), (28) і (15). Одержана в результаті система рівнянь з урахуванням реактивного характеру моментів сухого та зовнішнього в'язкого тертя, які спрямовані проти руху платформи 3 користувачем та коліс гіроборда, має такий вигляд:

$$
\begin{gathered}
m_{1} l_{1}\left(l_{1} \ddot{\alpha}+\ddot{x} \cos \alpha-g \sin \alpha\right)+c_{1-2}(\alpha-\theta)+b_{1-2}(\dot{\alpha}-\dot{\theta})=-M_{\text {3.p }} ; \\
m_{2} l_{2}\left(l_{2} \ddot{\theta}-\ddot{x} \cos \theta+g \sin \theta\right)-c_{1-2}(\alpha-\theta)-b_{1-2}(\dot{\alpha}-\dot{\theta})=M_{\text {3.p }}-M_{\text {д }}-\operatorname{sign}(\dot{\theta})\left(2 b_{2}|\dot{\theta}|+M_{\mathrm{c} .2}\right) ; \\
m_{\Sigma} \ddot{x}+m_{1} l_{1}\left(\ddot{\alpha} \cos \alpha-\dot{\alpha}^{2} \sin \alpha\right)-m_{2} l_{2}\left(\ddot{\theta} \cos \theta-\dot{\theta}^{2} \sin \theta\right)=\frac{M_{\text {д }}}{r_{\mathrm{K}}}-\operatorname{sign}(\dot{x})\left(\frac{2 b_{3}}{r_{\mathrm{K}}^{2}}|\dot{x}|+\frac{M_{\mathrm{c} .3}}{r_{\mathrm{K}}}+F_{\mathrm{r} . \mathrm{K}}\right) .
\end{gathered}
$$

\section{Розроблення функціональної схеми системи керування гіробордом}

На рис. 3 наведено функціональну схему системи керування гіробордом, яка побудована за аналогією 3 [12].

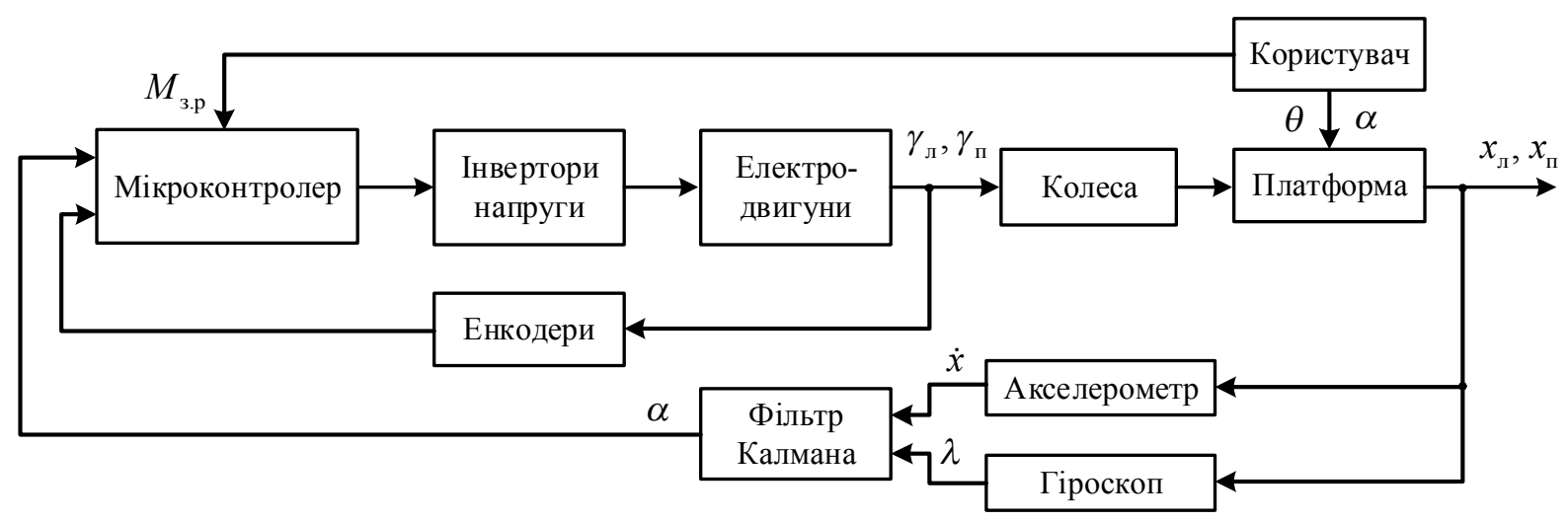

Рис. 3. Функиіональна схема системи керування гіробордом

Зі схеми видно, що користувач, нахиляючись вперед на кут $\alpha$ з метою руху, змінює кут нахилу платформи $\theta$, в результаті чого діє на два канали: безпосередньо змінює параметри об'єкта керування та задає команду мікроконтролерові на завдання моменту руху $M_{\text {з.р }}$. За останньою мікроконтролер формує завдання, а інвертори напруги та двигуни створюють крутні моменти коліс. Вимірювання акселерометра і гіроскопа після оброблення фільтром Калмана дають інформацію про кут нахилу користувача $\alpha$. У результаті мікроконтролер компенсує кут нахилу, коригуючи електромагнітні моменти привідних електродвигунів коліс гіроборда, щоб забезпечити стабільність користувача.

Користувач також подає команду повороту на ЕТЗ, повертаючи джойстик чи половини платформ на різний кут. Цю інформацію мікроконтролер сприймає як завдання на різні значення моментів коліс. Енкодери вимірюють кутове переміщення коліс з метою забезпечення векторного керування синхронних двигунів із постійними магнітами (СДПМ), а також зворотного зв'язку для кута повороту ЕТЗ. 


\section{3. Шур, Т. Я. Дзьоба, П. Й. Голубовський}

\section{Комп'ютерне симулювання роботи гіроборда}

3 метою комп'ютерного симулювання розраховано параметри гіроборда, призначеного для транспортування користувача масою до 130 кг зі швидкістю до 20 км/год та прискоренням до $0,1 \mathrm{~m} / \mathrm{c}^{2}$ під ухил $2 \%$. Інші параметри гіроборда: $r_{\mathrm{\kappa}}=0,1 \mathrm{м}, F_{\mathrm{T. \kappa}}=14 \mathrm{H}$. Для цих вихідних даних отримано такі параметри СДПМ: $P_{\mathrm{H}}=112 \mathrm{BT}, n_{\mathrm{H}}=2650$ об./хв, передавальне число редукторів $i=5$. Керування електродвигунами здійснюється за допомогою транзисторних інверторів напруги за принципом векторного керування згідно із інформацією про кути положення роторів від відповідних енкодерів.

На рис. 4 показано створену комп’ютерну модель роботи гіроборда, де змодельовано також поведінку користувача. Він задає бажану швидкість руху $V^{*}$ і контролює останню, змінюючи кут нахилу свого тіла. Це моделюється за допомогою від'ємного зворотного зв'язку за швидкістю руху гіроборда та регулятора швидкості РШ. Сформоване на виході останнього завдання на кут нахилу користувача alfa* виконується за допомогою регулятора кута РК, на вході якого alfa* порівнюється 3 реальним значенням цього кута alfa. Залежно від отриманої похибки формується завдання на момент руху Mh. Цей сигнал подається на підсистему Hyroboard Sybsystem, в якій здійснюється інтегрування одержаних диференціальних рівнянь (29)-(31), що описують роботу тримасової електромеханічної системи гіроборда. До цієї ж підсистеми надходять значення електромагнітних моментів двигунів коліс Md, які формуються у підсистемі електроприводів Drive Subsystem. Завдання на ці моменти формуються пропорційно до значень сигналів про кути нахилу платформи teta. У результаті комп'ютерних досліджень визначено доцільні структури РШ та РК пропорційно-диференціальні, а також знайдено їх параметри (рис. 4).

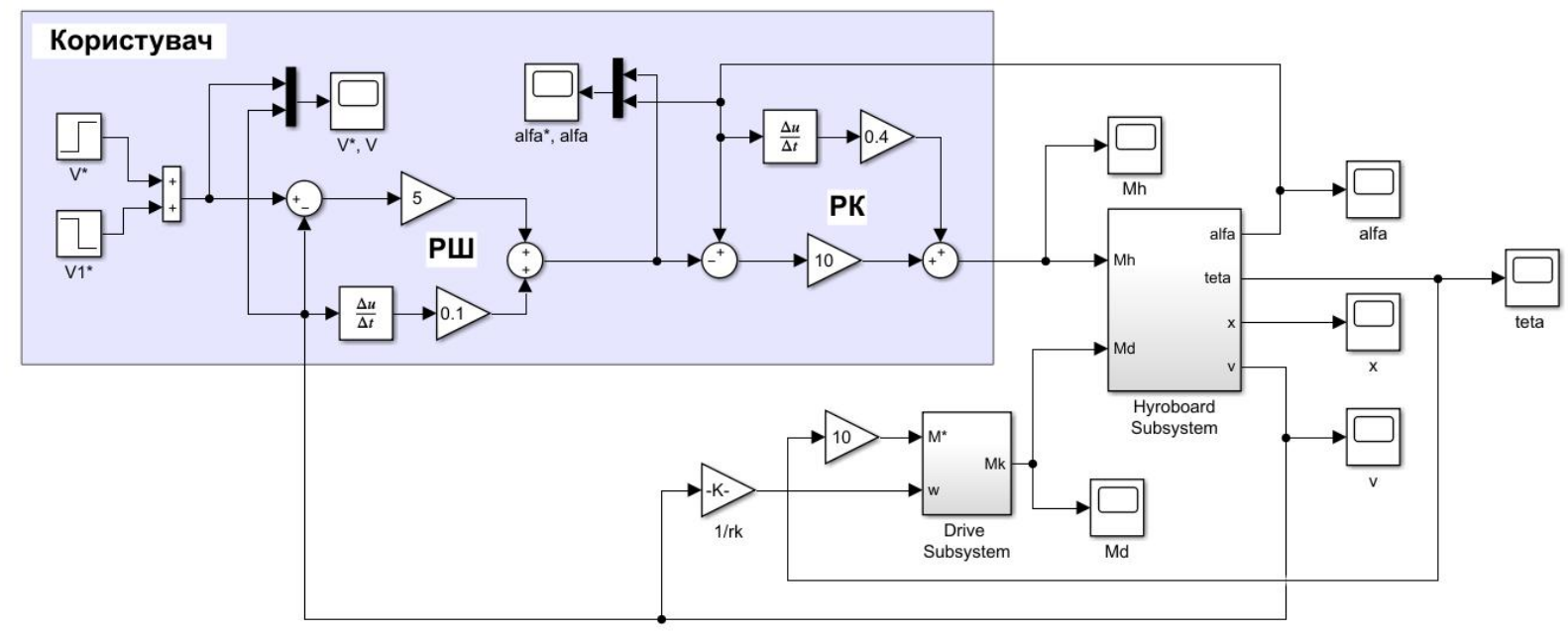

Pис. 4. Комп'ютерна модель роботи гіроборда з користувачем у середовищі Matlab/Simulink

У наведених на рис. 5 результатах симулювання користувач задає у момент часу 0,5 с бажану швидкість руху 0,3 м/с, а на 80 с він починає зупиняти гіроборд (рис. 4, a). На виході РШ формуються завдання на підпорядковану швидкості руху гіроборда координату кута нахилу користувача $\alpha h$ (рис. 4, б), значення якої порівнюється із реальним значенням кута нахилу користувача $\alpha$ (рис. 4, в). Відтак на виході РК формується завдання на підпорядковану куту нахилу користувача координату завдання моменту руху $M h$ (рис. 4, 2). За реальним кутом нахилу платформи teta (рис. 4, d) САК формує завдання на електромагнітний момент двигуна $M^{*}$, яке реалізується замкненою за струмами якоря системою керування у вигляді моменту $M d$ (рис. $4, e$ ). На виході з підсистеми Hyroboard Sybsystem отримують також такі координати, як швидкість $v$ руху 
Людино-машинне керування одновісним двоколісним персональним електричним транспортним засобом ...

гіроборда (рис. $4, \epsilon$ ) та шлях, який проходить гіроборд $x$ (рис. 4, ж). Результат роботи системи осцилограми, на початковому етапі яких відображено зміни користувачем завдання швидкості руху коливання, які пояснюються балансуванням тіла людини з метою збереження рівноваги.

Отже, отримані осцилограми показують перебіг процесів формування сигналів керування гіробордом, що відповідають бажанню користувача і його навичкам керування цим транспортним засобом, а також роботу САК і зміну координат руху гіроборда.

\section{Висновки}

Розроблена на основі рівняння Лагранжа II роду математична модель динамічних процесів руху гіроборда із пасажиром дала змогу побудувати відповідну комп'ютерну модель, за допомогою якої вдалося дослідити та зрозуміти закономірності роботи цього достатньо складного нелінійного та нестійкого об'єкта.
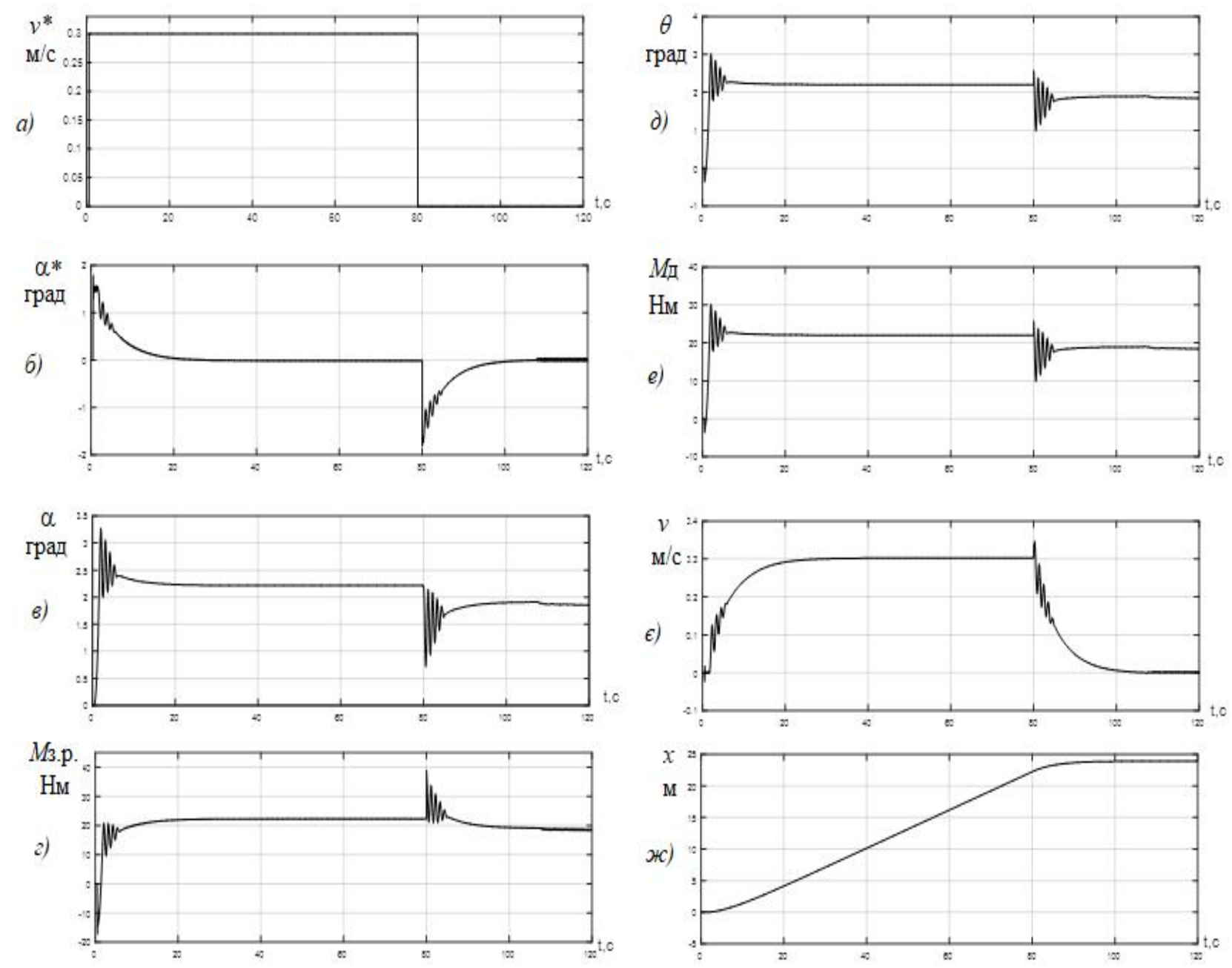

Рис. 5. Результати комп 'ютерного симулювання переміщення гіроборда із користувачем у вигляді часових діаграм: а-швидкість, яку задає користувач; б - кут нахилу тіла користувача, який він задав, град.; в - реальний кут нахилу користувача, град.; г - кут нахилу платформи гіроборда, град.; д -момент завдання руху; е-електромагнітний момент двигуна; $\epsilon$-швидкість руху гіроборда; ж-илях, який проїхав гіроборд

Людино-машинна система керування гіробордом поєднує набуті навички самобалансування користувача, які узгоджуються із розробленою системою керування приводами коліс гіроборда. 


\section{I. З. Щур, Т. Я. Дзьоба, П. Й. Голубовський}

Змодельована у середовищі Matlab/Simulink система гіроборда дала змогу отримати за допомогою комп'ютерного симулювання часові діаграми основних координат роботи, які підтверджують працездатність розроблених підходів до побудови системи керування гіробордом.

\section{Список використаних джерел}

1. Jeon D., Hong W.T., Choi H. Smart personal mobility (SPM) for service and entertainment // Proc. 11th ACM/IEEE Int. Conf. on Human-Robot Interaction (HRI), 2016, pp. 557.

2. Govardhan P., Thakre A., Shende N., Phadnis N., Muley S. Survey on self balancing two wheel electric prototype // Int. J. Engineering Research and General Science, 2017, vol. 5, Is. 5, pp. 32-36.

3. Draz M. U., Ali M. S., Majeed M., Ejaz U., Izhar U. Segway electric vehicle // Proc. Int. Conf. Robotics and Artificial Intelligence, 2012, pp. 34-39.

4. Cardozo G. S. S., Vera L. M. S. Prototype for a self-balanced personal transporter // Proc. 2012 Workshop on Engineering Applications, 2012, pp. 1-6.

5. Семенов М. Е., Хатиф 3., Решетова О. О., Демчук А. А., Мелешенко П. А. Модель динамики обратного маятника с гистерезисным управлением // Вест. Воронеж. гос. ун-та. Серия: Физика. Математика. 2016. № 4. С. 165-177.

6. Эмирбеков Н. Э., Эмирбеков М. Э. Разработка алгоритмов раскачки и стабилизации обратного маятника, закрепленного на валу двигателя // Автоматика и программная инженерия. - 2016, № 1(15). - С. $38-43$.

7. Burket M. Segway design project // IEEE Trans. On industry applications. - 2007, vol. 43, No. 3, pp. 769-776.

8. Khan M. H., Chaudhry M., Tariq T., Fatima Q.-ul-A., Izhar U. Fabrication and modelling of segway // Proc. 2014 IEEE Int. Conf. on Mechatronics and Automation, August 3-6, Tianjin, China, pp. 280-285.

9. Babazadeh R., Khiabani A. G., Azmi H. Optimal control of Segway personal transporter // Proc. 4th Int. Conf. on Control, Instrumentation, and Automation (ICCIA), 27-28 January 2016, Qazvin, Iran, pp. 18-22.

10. Renet J. Motion control for a two-wheeled vehicle using a self-tuning PID controller // Control Engineering Practice, 2008, vol. 16, pp. 365-375.

11. Miranda J. Application of Kalman filtering and PID control for direct inverted pendulum control // IEEE Trans. Smart Ggrid, 2014, vol. 5, No. 2, pp. 944-953.

12. Mohtasib A. M., Shawar M. H. Self-balancing two-wheel electric vehicle (STEVE) // Proc. 9th Int. Symp. on Mechatronics and its Applications (ISMA13), Amman, Jordan, April 9-11, 2013, pp. 1-8.

13. Ahmad S., Siddique N. H., Tokhi M. O. A modular fuzzy control approach for two-wheeled wheelchair // J. of Intelligent \& Robotic Systems. - Springer Science+Business Media B. V., 2011, vol. 64, Is. 3-4, pp. 401-426.

14. Kwak S., Choi B.-J. Design of fuzzy logic control system for Segway type mobile robots // Int. J. of Fuzzy Logic and Intelligent Systems, 2015, vol. 15(2), pp. 126-131.

15. Gu D.-W., Petkov P.H., Konstantinov M. M. Robust control of self-balancing two-wheeled robot // Robust Control Design with MATLAB ${ }^{\circledR}$, Springer, 2018, pp. 435-454.

16. Литвинов О. I. Теоретична механіка. Ч. ІІ. Динаміка. Основи аналітичної механіки / О. І. Литвинов, Я. М. Михайлович, А. В. Бойко, М. Г. Березовий. К.: Агроосвіта, 2013. - 576 с.

\section{References}

1. Jeon D., Hong W. T., Choi H. Smart personal mobility (SPM) for service and entertainment // Proc. 11th ACM/IEEE Int. Conf. on Human-Robot Interaction (HRI), 2016, pp. 557.

2. Govardhan P., Thakre A., Shende N., Phadnis N., Muley S., Survey on self balancing two wheel electric prototype // Int. J. Engineering Research and General Science, 2017, vol. 5, Is. 5, pp. 32-36.

3. Draz M. U., Ali M. S., Majeed M., Ejaz U., Izhar U. Segway electric vehicle // Proc. Int. Conf. Robotics and Artificial Intelligence, 2012, pp. 34-39.

4. Cardozo G. S. S., Vera L. M. S. Prototype for a self-balanced personal transporter // Proc. 2012 Workshop on Engineering Applications, 2012, pp. 1-6.

5. Siemionov M. E. Modiel' dinamiki obratnogo mayatnika s gisterezisnym upravlieniyem [Model of an inverse pendulum dynamics with hysteresis control] / M. E. Siemionov, Z. Khatif, O. O. Rieshetova, A. A. Diemchuk, P. A. Mielieshko // Viestnik Voroniehzskogo Gosudarstviennogo Universitieta. Sieriya: Fizika. Matiematika [Bulletin of the Voronezh State University. Series: Physics. Maths.], 2016, No. 4, pp. 165-177. 
Людино-машинне керування одновісним двоколісним персональним електричним транспортним засобом ...

6. Emirbekov N. E., Emirbekov M. E. Razrabotka algoritmov raskachki I stabilizatsii obratnogo mayatnika, zakrieplionnogo na valu dvigatielia [Development of algorithms for the buildup and stabilization of a reverse pendulum fixed on the motor shaft] // Automatika i programnaya inhzenieriya [Automation and software engineering]. 2016, No. 1 (15), pp. 38-43.

7. Burket M. Segway design project // IEEE Trans. On industry applications, 2007, vol. 43, No. 3, pp. 769-776.

8. Khan M. H., Chaudhry M., Tariq T., Fatima Q.-ul-A., Izhar U. Fabrication and modelling of segway // Proc. 2014 IEEE Int. Conf. on Mechatronics and Automation, August 3-6, Tianjin, China, pp. 280-285.

9. Babazadeh R., Khiabani A. G., Azmi H. Optimal control of Segway personal transporter // Proc. 4th Int. Conf. on Control, Instrumentation, and Automation (ICCIA), 27-28 January 2016, Qazvin, Iran, pp. 18-22.

10. Renet J. Motion control for a two-wheeled vehicle using a self-tuning PID controller // Control Engineering Practice. 2008. Vol. 16. P. 365-375.

11. Miranda J. Application of Kalman filtering and PID control for direct inverted pendulum control // IEEE Trans. Smart Ggrid, 2014, vol. 5, No. 2, pp. 944-953.

12. Mohtasib A. M., Shawar M. H. Self-balancing two-wheel electric vehicle (STEVE) // Proc. 9th Int. Symp. on Mechatronics and its Applications (ISMA13), Amman, Jordan, April 9-11, 2013, pp. 1-8.

13. Ahmad S., Siddique N. H., Tokhi M. O. A modular fuzzy control approach for two-wheeled wheelchair // J. of Intelligent \& Robotic Systems, Springer Science+Business Media B. V., 2011, vol. 64, Is. 3-4, pp. 401-426.

14. Kwak S., Choi B.-J. Design of fuzzy logic control system for Segway type mobile robots // Int. J. of Fuzzy Logic and Intelligent Systems, 2015, vol. 15(2), pp. 126-131.

15. Gu D.-W., Petkov P. H., Konstantinov M. M. Robust control of self-balancing two-wheeled robot // Robust Control Design with MATLAB®, Springer, 2018, pp. 435-454.

16. Lytvynov O. I. Teoretychna Mekhanika. Ch. II. Dynamika. Osnovy Analitychnoyi Mekhaniky [Theoretical mechanics. Ch. II. Dynamics. Fundamentals of Analytical Mechanics] / O. I. Lytvynov, Ya. M. Mykhaylovych, A. V. Boyko, M. H. Berezovyi. Kyiv.: Agroosvita, 2013. 576 p.

I. Z. Shchur

Lviv Polytechnic National University, Department of electromechatronics and computerized electromechanical systems, i_shchur@meta.ua

T. Y. Dzoba

Lviv Polytechnic National University, Department of Electromechatronics and Computerized Electromechanical Systems, tdzoba@gmail.com,

P. Y. Holubovskyi

Lviv Polytechnic National University, Department of Electromechatronics and Computerized Electromechanical Systems, sumixlviv@ukr.net

\title{
HUMAN-MACHINE CONTROLLING OF ONE-AXIS TWO-WHEEL PERSONAL ELECTRIC VEHICLE IN THE CASE OF LINER MOVEMENT
}

\author{
(C) Shchur I. Z., Dzoba T. Y., Holubovskyi P. Y., 2019
}

The paper deals with a new kind of personal electric vehicle (EV) - a segway or a gyroboard, in which a user, in motion control, takes direct part in balancing of his position with respect to the axis connecting two wheels with self electric drives. Such EV is a complex human-machine system, whose work depends on human commands and on the corresponding reaction of the movement automatic control system (ACS). Therefore, for the development of the latter, it is necessary to know the work 


\section{I. З. Щур, Т. Я. Дзьоба, П. Й. Голубовський}

regularities of the electromechanical system of this $\mathrm{EV}$, as well as the skills in management acquired by the user. Based on the Lagrange II equation, the mathematical model of the motion kinematics of such an $\mathrm{EV}$ in the form of a nonlinear system of interconnected differential equations of the second order is developed. As systems of electric drives of the wheels, synchronous machines with permanent magnets are used and controlled by voltage transistor inverters based on the positions of their rotors in accordance with signals from encoders linked with the wheels. The references on the electromagnetic torques of the wheel drives are formed by the PD regulators based on the signals from the sensor system solid-state gyroscope and accelerometer, which allow to determine the angle of inclination of the user's body. According to the developed functional scheme of the system "user - gyroboard", the simulation computer model is created in the environment of Matlab/Simulink, which includes the developed mathematical model of kinematics motion of gyrobord with the user, simulates the behavior of the latter, as well as the work of ACS of wheels electric drives. The rational settings of the regulators are defined from this model. As a result of the computer simulation of the cycle of the gyroboard motion, a series of waveforms of the main variables describing the dynamics of the system was obtained. They made it possible to understand the laws of interaction between user and machine and showed the efficiency of developed approaches to the construction of a gyroboard control system.

Key words: personal electric vehicle; segway; gyroboard; self-balancing; human-machine system 